\title{
ONE HEALTH: ANTIBIOTIC-RESISTANT BACTERIA CONTAMINATION IN FRESH VEGETABLES SOLD AT A RETAIL MARKETS IN KYIV, UKRAINE
}

10.36740/WLek202101116

\author{
Aidyn G. Salmanov', Valerii O. Ushkalov'², Yelizaveta Ye. Shunko' , Natalie Piven' ${ }^{1}$ Liliia M. Vygovska², \\ Olha M. Verner', Stella Kushnirenko ${ }^{1}$ \\ 'SHUPYK NATIONAL MEDICAL ACADEMY OF POSTGRADUATE EDUCATION, KYIV, UKRAINE \\ ${ }^{2}$ NATIONAL UNIVERSITY OF LIFE AND ENVIRONMENTAL SCIENCES OF UKRAINE, KYIV, UKRAINE
}

\begin{abstract}
The aim: To obtain the first estimates data on the occurrence of antibiotic-resistant bacteria in a wide range of fresh vegetables available in the Kyiv city markets. Materials and methods: We performed a multicenter study. Fresh vegetables samples were collected of the six different commodity groups from eleven of retail stores located in Kyiv, Ukraine. Samples were tested for up to eight bacteria of concern. The susceptibility to antibiotics was determined by disk diffusion method according to the European Committee on Antimicrobial Susceptibility Testing.

Results: The antibiotic-resistant bacteria contamination in the fresh vegetables was $24.3 \%$. The contamination among organic produce was significantly higher than in conventionally products. Contamination was found to be higher in leafy vegetables. The predominant contaminated bacteria were: Escherichia coli, Enterobacter spp. and Enterococcus faecalis, followed by Klebsiella pneumoniae, Pseudomonas aeruginosa, E. faecium, Staphylococcus aureus and Acinetobacter spp. The overall proportion of extended spectrum beta-lactamase (ESBL) production among Enterobacteriaceae was $36.8 \%$ and of methicillin-resistance in S. aureus (MRSA) $10.7 \%$. The prevalence of ESBL production among E. coli isolates was significantly higher than in K. pneumoniae. Vancomycin resistance was observed in $3.1 \%$ of isolated enterococci (VRE). Carbapenem resistance was identified in $35.3 \%$ of P.aeruginosa isolates and $66.8 \%$ of Acinetibacter spp. isolates. Resistance to third-generation cephalosporins was observed in $9.7 \%$ K. pneumoniae and E.coli in $14.2 \%$ isolates.

Conclusions: Research has shown that the majority of fresh vegetables available in Kiev markets is contaminated with antibiotic-resistant bacteria and is a potential vehicle for the transmission of these pathogens to consumers.
\end{abstract}

KEY WORDS: Fresh Vegetables, Bacterial contamination, Retail, Antimicrobial Resistance, Ukraine

Wiad Lek. 2021;74(1):83-89

\section{INTRODUCTION}

Fresh vegetables are well recognized as important parts of a nutritious and healthy diet of human worldwide. Therefore, consumers demand the variety and availability of these products all year round. This has impacted international trade in Ukraine, where many fresh fruits and vegetables are imported. Currently, Ukraine is a importer of fresh fruits and vegetables year round (leafy greens, soft fruits, citrus fruits, grapes, cauliflower, broccoli, onions, bananas, beans and carrots, peppers, tomatoes, avocados, cucumbers and asparagus).

In recent years, internationally, there has been an increasing the number of outbreaks of fresh produce-associated foodborne illness and efforts are being made to resolve these problems [1-5]. Are more frequently linked to these outbreaks; for example, leafy greens, such as lettuce [6] and spinach [7, $8]$, and fresh herbs, such as parsley and basil $[9,10]$, green onions [6], tomatoes [11], watermelon [12], are well-recognized potential sources of bacterial infections $[4,5,7,9]$. As with other countries, Ukraine has seen an increased number of foodborne illness outbreaks linked to fresh produce in the last decades. However, there are no published data on human outbreaks associated with fresh vegetables in Ukraine.

The potential for transfer of antibiotic-resistant bacteria from fresh vegetables into the human population is cause for concern. The success of treating infectious patients, including in foodborne outbreaks, depends on many factors, including resistance to infectious agents due to antimicrobial activity. Optimally, a given antibiotic should be selected based on the safety profile and local drug susceptibility. However, in Ukraine, there is no targeted surveillance for emerging microbiological hazards including antibiotic-resistance bacteria contamination in fresh vegetables at the retail level. The previous reports of antimicrobial resistance in Ukraine have been limited only to healthcare-associated infections $[13,14]$.

\section{THE AIM}

The aim of this study was to obtain the first estimates data on the occurrence of antibiotic-resistant bacteria in a wide range of fresh vegetables available in the Kyiv city markets. 


\section{MATERIALS AND METHODS}

\section{STUDY DESIGN AND SAMPLING COLLECTION}

We performed a multicenter study. Samples were collected between January 1st, 2017 and December 31st, 2019 for each of the six fresh vegetables commodity groups (leafy vegetables, leafy herbs, green onions, cucumbers, berries and tomatoes) from eleven of retail stores located in Kyiv, Ukraine.

The retail stores were selected based on geographic and demographic considerations and the corresponding number of samples was collected in proportion to the relative population of the respective areas of Kyiv city, Ukraine. The goal of this sampling approach was to obtain a large set of samples that would be representative of the targeted food commodities available to Ukrainians in Kyiv city at retail during the time of the study (Table I).

The number of fresh vegetables samples collected in each season was impacted by the availability of the targeted commodity in the Ukrainian market at the time of sampling. Domestic samples were collected during the summer months and imported samples were collected primarily in the fall, winter and spring months. The target sample population consisted of all units of the targeted commodity available at retail to consumers as per the sampling design.

\section{MICROBIOLOGICAL METHODS}

In this study samples from fresh vegetables were analysed for the presence of up to eight bacterial species (Staphylococcus aureus, Enterococcus faecalis, Enterococcus faecium, Escherichia coli, Enterobacter spp., Klebsiella pneumoniae, Pseudomonas aeruginosa, and Acinetibacter spp.) using the methods published in Ministry of Health of Ukraine Compendium of Analytical Methods for the Microbiological Analysis of Foods. These methods have been fully validated for the analysis of fresh fruits and vegetables and are used for the regulatory testing of foods and in food safety investigations. The analyses of bacterial pathogens were performed using enrichment methods, confirmed by isolation, purification and identification procedures. These analyses were done on $25 \mathrm{~g}$ of sample. Samples where bacterial pathogens were detected and confirmed in 25 $\mathrm{g}$ of products, or where generic E. coli levels were found to be $>100 \mathrm{CFU}$ or MPN/g, were reported as positive. Microbial isolates were identified using standard microbiological techniques, including automated microbiology testing (Vitek-2; bioMe' rieux, Marcy l'Etoile, France), and antibiotic susceptibility testing was performed by using the disk diffusion method (Kirby - Bauer antibiotic testing). Isolates were categorized as susceptible or resistant by Clinical and Laboratory Standards Institute criteria (CLSI, 2013). Strains in the intermediate range were classified as resistant for data analysis.

\section{ETHICS}

The study was approved by the Ethics Committee of Shupyk National Medical Academy of Postgraduate Education (Kyiv, Ukraine).

\section{STATISTICAL ANALYSIS}

A statistical methodology was developed to investigate the presence of the seven bacterial species in the chosen fresh vegetables over the three years of sampling. The analyses are based on the percentage of positive samples for a given bacterial species and for all bacterial species combined (i.e., global sample result). The analysis of statistical data was performed using Excel (Microsoft Corp., Redmond, WA, USA). Results are expressed as median (range), mean standard deviation for continuous variables, and number and corresponding percentage for qualitative variables. The estimated prevalence is defined as the overall percentage of positive samples - either for a given bacterium or for all bacteria studied (global sample result). The Wilson confidence interval (i.e., a two-sided 95\% confidence interval for the proportion) was used to estimate the prevalence of bacteria. Statistical significance was defined as $P<0.05$.

\section{RESULTS}

\section{ANTIBIOTIC-RESISTANT BACTERIA CONTAMINATION}

A total 13,694 of fresh vegetables samples for six different commodity groups were collected and tested for the presence of a variety of bacteria over a three year period (January 1st, 2017 and December 31st, 2019). The prevalence of the antibiotic-resistant bacteria contamination in fresh vegetables was $24.3 \%(3,326 / 13,694)$ [95\% CI 24\%, 24.6\%, p <0.0001].

The contaminated fresh vegetables samples consisted of imported and domestic products $(3.1 \%$ and $21.2 \%$, respectively), including a conventionally and organically grown products (5.1\% and 19.2\%). The prevalence of the bacterial contamination were: leafy vegetables - 34.6\% [95\% CI 33.6\%, $35.6 \%, \mathrm{p}<0.0001]$, leafy herbs - $40.4 \%$ [95\% CI $39.5 \%, 41.3 \%$, $\mathrm{p}<0.0001$ ], tomatoes $-8.6 \%$ [95\% CI 8.0\%, 9.2\%, $\mathrm{p}<0.0001$ ], green onions $-15.9 \%$ [95\% CI 15.1\%, 16.7\%, $\mathrm{p}<0.0001$ ], cucumbers - $11.6 \%$ [95\% CI 10.9\%, 12.3\%, $\mathrm{p}<0.0001]$ and berries - 30.7\% [95\% CI 29.7\%, 31.7\%, p <0.0001]. Positive rates and prevalence of bacterial contamination in all commodities are summarized in Table II.

The predominant contaminated fresh vegetables were: strawberries $(73 \%, 95 \%$ CI $71.1 \%, 74.9 \%)$, parsley $(66.1 \%$, 95\% CI 64.3\%, 67.9\%), dill (42.3\%, 95\% CI 40.0\%, 44.4\%), cilantro (40.4\%, 95\% CI 38.3\%, 42.5\%), leaf lettuce (38.9\%, $95 \%$ CI $36.7 \%, 40.9 \%)$, spinach $(38 \%, 95 \%$ CI $36.0 \%$, $40.0 \%)$, basil $(35.4 \%, 95 \%$ CI 33.4\%, 37.4\%) and mixed greens $(33.2 \%, 95 \%$ CI $31.2 \%, 35.2 \%)$, followed by head lettuce $(26.4 \%, 95 \%$ CI $24.9 \%, 29.1 \%)$ and blueberries (26.1\%, 95\% CI 24.1\%, 28.1\%). Low bacterial contamination has been found in tomatoes $(8.6 \%, 95 \% \mathrm{CI} 8.0 \%, 9.2 \%)$, raspberries $(10.7 \%, 95 \%$ CI 9.2\%, 12.2\%) and cucumbers (11.5\%, 95\% CI 10.9\%, 12.3\%).

\section{BACTERIAL PATHOGENS IN FRESH VEGETABLES}

A total of 8179 strains isolated from 3326 contaminated fresh vegetables. Gram-positive organisms accounted for 
Table I. Number of samples by commodity groups

\begin{tabular}{|c|c|c|c|c|c|}
\hline \multirow{3}{*}{ Commodity } & \multirow{3}{*}{$\begin{array}{c}\text { Total } \\
(n=13694)\end{array}$} & \multicolumn{4}{|c|}{ Number of samples } \\
\hline & & \multicolumn{2}{|c|}{ Product Origin } & \multicolumn{2}{|c|}{ Production Type } \\
\hline & & Domestic & Imported & Conventional & Organic \\
\hline Leafy Vegetables & 2132 & 1594 & 538 & 465 & 1667 \\
\hline Leafy Herbs & 2812 & 2390 & 422 & 597 & 2215 \\
\hline Tomatoes & 2332 & 1007 & 1325 & 996 & 1336 \\
\hline Green Onions & 2014 & 1738 & 276 & 131 & 1883 \\
\hline Cucumbers & 2212 & 955 & 1257 & 936 & 1276 \\
\hline Berries & 2192 & 1499 & 693 & 716 & 1476 \\
\hline
\end{tabular}

Table II. Bacterial contamination in fresh vegetables

\begin{tabular}{|c|c|c|c|c|c|}
\hline \multirow{3}{*}{ Commodity } & \multirow{3}{*}{$\begin{array}{l}\text { Number } \\
\text { of samples }\end{array}$} & \multicolumn{4}{|c|}{ Number of positive samples } \\
\hline & & \multicolumn{2}{|c|}{ Product Origin } & \multicolumn{2}{|c|}{ Production Type } \\
\hline & & Domestic & Imported & Conventional & Organic \\
\hline Leafy Vegetables & 2132 & $\begin{array}{c}642 \\
(30.1 \%) \\
\end{array}$ & $\begin{array}{c}96 \\
(4.5 \%) \\
\end{array}$ & $\begin{array}{c}112 \\
(5.3 \%) \\
\end{array}$ & $\begin{array}{c}626 \\
(29.3 \%) \\
\end{array}$ \\
\hline $\begin{array}{l}\text { Leafy } \\
\text { Herbs }\end{array}$ & 2812 & $\begin{array}{c}1012 \\
(35.6 \%)\end{array}$ & $\begin{array}{c}124 \\
(4.4 \%)\end{array}$ & $\begin{array}{c}167 \\
(5.9 \%)\end{array}$ & $\begin{array}{c}969 \\
(34.1 \%)\end{array}$ \\
\hline Tomatoes & 2332 & $\begin{array}{c}145 \\
(6.2 \%) \\
\end{array}$ & $\begin{array}{c}56 \\
(2.4 \%) \\
\end{array}$ & $\begin{array}{c}58 \\
(2.5 \%) \\
\end{array}$ & $\begin{array}{c}143 \\
(6.1 \%)\end{array}$ \\
\hline Green Onions & 2014 & $\begin{array}{c}289 \\
(14.3 \%)\end{array}$ & $\begin{array}{c}32 \\
(1.6 \%)\end{array}$ & $\begin{array}{c}93 \\
(4.6 \%)\end{array}$ & $\begin{array}{c}228 \\
(11.3 \%)\end{array}$ \\
\hline Cucumbers & 2212 & $\begin{array}{c}240 \\
(10.8 \%)\end{array}$ & $\begin{array}{c}16 \\
(0.7 \%)\end{array}$ & $\begin{array}{c}76 \\
(3.4 \%)\end{array}$ & $\begin{array}{c}180 \\
(8.1 \%)\end{array}$ \\
\hline Berries & 2192 & $\begin{array}{c}579 \\
(26.4 \%) \\
\end{array}$ & $\begin{array}{c}95 \\
(4.3 \%) \\
\end{array}$ & $\begin{array}{c}189 \\
(8.6 \%) \\
\end{array}$ & $\begin{array}{c}485 \\
(22.1 \%) \\
\end{array}$ \\
\hline Total & 13694 & $\begin{array}{c}2907 \\
(21.2 \%)\end{array}$ & $\begin{array}{c}419 \\
(3.1 \%)\end{array}$ & $\begin{array}{c}695 \\
(5.1 \%)\end{array}$ & $\begin{array}{c}2631 \\
(19.2 \%)\end{array}$ \\
\hline
\end{tabular}

$27 \%$ [95\% CI 26.5\%, 27.5\%, p <0.0001] of all strains and gram-negative organisms accounted 73\% [95\% CI 72.5\%, $73.5 \%, \mathrm{p}<0.0001$ ], respectively. Enterobacteriaceae were the most frequently isolated group of organisms from contaminated fresh vegetables $(64.3 \%$, 95\% CI $63.8 \%$, $64.8 \%, \mathrm{p}<0.0001)$. The predominant pathogens were: E. coli $(35.8 \%, 95 \%$ CI 35.3\%, 36.3\%), Enterobacter spp. $(17.8 \%, 95 \%$ CI $17.4 \%, 18.2 \%)$ and $E$. faecalis $(17.1 \%, 95 \%$ CI 16.7\%, 17.5\%), followed by K. pneumoniae (10.7\%, 95\% CI $10.4 \%, 11 \%)$, P. aeruginosa $(6.5 \%, 95 \%$ CI $6.2 \%, 6.8 \%)$, E. faecium (6\%, 95\% CI 5,3\%, 6,7\%), S. aureus (4\%, 95\% CI $3.8 \%, 4.2 \%)$ and Acinetobacter spp. $(2.2 \%, 95 \%$ CI $2.0 \%$, 2.4\%) (Table III and IV).

\section{ANTIMICROBIAL RESISTANCE}

Because most commensally bacteria have natural gene transfer mechanisms and can be resistant to multiple antimicrobials, it is important to characterize the strains that have been isolated from food. Antimicrobial susceptibility tests were performed on a total of 2260 isolates of Gram-positive cocci and 5919 gram-negative organisms. The antimicrobials used in antimicrobial susceptibility testing included those commonly used as therapeutic agents. Varying degrees of resistance to most antimicrobials tested were found.

The staphylococcal isolates displayed a remarkable resistance to penicillin (83.1\%) and erythromycin (65.2\%), although there were some differences depending on the fresh vegetables. Staphylococcal isolates showed susceptibility to most of the other antimicrobials tested. No strains resistant to linezolid, teicoplanin, vancomycin, tigecycline, and fusidic acid were found. Methicillin-resistance was observed in $10.7 \%$ of S. aureus. Regarding the genus Enterococcus, E. faecalis isolates and E. faecium were not sensitive to those antibiotics to which they are intrinsically resistant (cefuroxime, clindamycin, and trimethoprim-sulfamethoxazole) and $85.3 \%$ of them were resistant to erythromycin. Approximately, 19\% of the E. faecalis isolates displayed resistance to high levels of aminoglycosides (gentamycin, tobramycin) and around $7.9 \%$ was resistant to quinolones (ciprofloxacin and levofloxacin), and $4 \%$ to glycopeptides (vancomycin and teicoplanin). Vancomycin resistance was observwd in $3.1 \%$ of isolated enterococci (VRE).

The overall proportion of extended spectrum beta-lactamases (ESBL) production among Enterobacte- 
Table III. Distribution of gram-positive organisms in fresh vegetables.

\begin{tabular}{|c|c|c|c|c|}
\hline \multirow{2}{*}{ Commodity } & \multirow{2}{*}{$\begin{array}{c}\text { Number } \\
\text { of samples }\end{array}$} & \multicolumn{3}{|c|}{ Microorganism } \\
\hline & & S. aureus & E. faecalis & E. faecium \\
\hline Leafy Vegetables & 1826 & $82(4.5 \%)$ & 394 (21.6\%) & $122(6.7 \%)$ \\
\hline Leafy Herbs & 2634 & $54(2.1 \%)$ & 264 (10\%) & $103(3.9 \%)$ \\
\hline Tomatoes & 685 & $97(14.2 \%)$ & $164(23.9 \%)$ & $43(6.3 \%)$ \\
\hline Green Onions & 1032 & 42 (4.1\%) & 122 (11.8\%) & $69(6.7 \%)$ \\
\hline Cucumbers & 697 & $72(10.3 \%)$ & $186(26.7 \%)$ & $39(5.6 \%)$ \\
\hline Berries & 1355 & $27(2 \%)$ & 268 (19.8\%) & $112(8.3 \%)$ \\
\hline Total & 8179 & $324(4 \%)$ & $1398(17.1 \%)$ & $488(6 \%)$ \\
\hline
\end{tabular}

Table IV. Distribution of gram-negative organisms in fresh vegetables

\begin{tabular}{|c|c|c|c|c|c|c|}
\hline & \multirow{2}{*}{$\begin{array}{c}\text { Number } \\
\text { of samples }\end{array}$} & \multicolumn{5}{|c|}{ Microorganism } \\
\hline & & E.coli & Enterobacter spp. & K.pneumoniae & P. aeruginosa & Acinetibacter spp. \\
\hline Leafy Vegetables & 1826 & $\begin{array}{c}734 \\
(40.2 \%)\end{array}$ & $\begin{array}{c}224 \\
(12.3 \%)\end{array}$ & $\begin{array}{c}121 \\
(6.6 \%) \\
\end{array}$ & $\begin{array}{c}118 \\
(6.5 \%) \\
\end{array}$ & $\begin{array}{c}31 \\
(1.7 \%) \\
\end{array}$ \\
\hline Leafy Herbs & 2634 & $\begin{array}{c}1122 \\
(42.6 \%) \\
\end{array}$ & $\begin{array}{c}661 \\
(25.1 \%) \\
\end{array}$ & $\begin{array}{c}257 \\
(9.8 \%) \\
\end{array}$ & $\begin{array}{c}134 \\
(5.1 \%) \\
\end{array}$ & $\begin{array}{c}39 \\
(1.5 \%) \\
\end{array}$ \\
\hline Tomatoes & 685 & $\begin{array}{c}143 \\
(20.9 \%)\end{array}$ & $\begin{array}{c}97 \\
(14.2 \%)\end{array}$ & $\begin{array}{c}89 \\
(13 \%)\end{array}$ & $\begin{array}{c}29 \\
(4.2 \%)\end{array}$ & $\begin{array}{c}23 \\
(3.4 \%)\end{array}$ \\
\hline Green Onions & 1032 & $\begin{array}{c}297 \\
(28.8 \%)\end{array}$ & $\begin{array}{c}211 \\
(20.4 \%)\end{array}$ & $\begin{array}{c}137 \\
(13.3 \%)\end{array}$ & $\begin{array}{c}121 \\
(11.7 \%)\end{array}$ & $\begin{array}{c}33 \\
(3.2 \%) \\
\end{array}$ \\
\hline Cucumbers & 697 & $\begin{array}{c}168 \\
(24.1 \%) \\
\end{array}$ & $\begin{array}{c}83 \\
(11.9 \%) \\
\end{array}$ & $\begin{array}{c}94 \\
(13.5 \%) \\
\end{array}$ & $\begin{array}{c}31 \\
(4.4 \%) \\
\end{array}$ & $\begin{array}{c}24 \\
(3.4 \%) \\
\end{array}$ \\
\hline Berries & 1355 & $\begin{array}{c}462 \\
(34.1 \%) \\
\end{array}$ & $\begin{array}{c}177 \\
(13.1 \%) \\
\end{array}$ & $\begin{array}{c}179 \\
(13.2 \%) \\
\end{array}$ & $\begin{array}{c}101 \\
(7.5 \%) \\
\end{array}$ & $\begin{array}{c}29 \\
(2.1 \%) \\
\end{array}$ \\
\hline Total & 8179 & $\begin{array}{c}2926 \\
(35.8 \%)\end{array}$ & $\begin{array}{c}1453 \\
(17.8 \%)\end{array}$ & $\begin{array}{c}877 \\
(10.7 \%)\end{array}$ & $\begin{array}{c}534 \\
(6.5 \%)\end{array}$ & $\begin{array}{c}179 \\
(2.2 \%)\end{array}$ \\
\hline
\end{tabular}

riaceae was $36.8 \%$. The prevalence of ESBL production among $E$. coli isolates was significantly higher than in K. pneumoniae $(33.5 \%$, vs $14.8 \%, \mathrm{p}<0.001)$. E.coli was most sensitive ( $>95 \%)$ to ertapenem (100\%), cefotaxime (99.1\%), ceftazidime (99.4\%), fosfomycin (98.7\%), imipenem (98.9\%), piperacillin/tazobactam (97.3\%), and gentamycin $(94.5 \%)$ but least susceptibility $(<70 \%)$ was observed for moxifloxacin $(54.2 \%)$, cefuroxime (65.8\%), amoxicillin (67.3\%), and levofloxacin (68.5\%). Resistance to third-generation cephalosporins was observed in $14.2 \%$ E.coli isolates. No strains of E.coli resistant to ertapenem were found. Enterobacter spp. isolates ones exhibited a noticeable percentage of resistance against ampicillin/ sulbactam (61.9\%), amoxicillin/clavulanic acid (60.2\%), ciprofloxacin $(47.8 \%)$, clindamycin $(52.2 \%)$, ampicillin (52.1\%), amikacin (43.8\%), and gentamycin (43.5\%), cefaperazon $(41.3 \%)$ and ceftriaxon (34.1\%). No strains of Enterobacter spp. resistant to cefepime, meropenem, imipenem, and ertapenem were found. K. pneumoniae isolates showed susceptibility to most of the other antimicrobials tested, while these isolates ones exhibited a noticeable percentage of resistance against ampicillin (51.5\%), amoxicillin/clavulanic acid (41.4\%), ofloxacin (33.1\%), and ciprofloxacin (29.7\%). No strains resistant to piperacillin/tazobactam and ertapenem were found. Re- sistance to third-generation cephalosporins was observed in $9.7 \%$ K. pneumoniae isolates. Carbapenem resistance was identified in $35.3 \%$ of P.aeruginosa isolates and $66.8 \%$ of Acinetibacter spp. isolates.

In isolates from fresh vegetables, the proportions of ESBL production were higher in domestic products (33.1\% vs $3.7 \%, p<0.001)$. Compared with organic production, isolates from domestic conventional products were also more frequently resistant to aminoglycosides $(23.3 \%$, vs $13.0 \%, p=0.031)$ and fluoroquinolones $(31.7 \%$ vs $8.3 \%$, $\mathrm{p}<0.001)$. All vancomycin-resistant enterococci and carbopenem-resistant $P$. aeruginosa were isolated from domestic conventional products.

\section{DISCUSSION}

This is the first study were to obtain of the current prevalence of the occurrence of antibiotic-resistant bacteria contamination in a wide range of fresh vegetables available in the city markets of Ukraine. In this study the antibiotic-resistant bacteria contamination in the fresh vegetables was $24.3 \%$. The contamination among organic produce was significantly higher than in conventionally products. Contamination of leafy vegetables by the bacterial pathogens investigated was found to be frequent 
and widespread occurrence. Leafy vegetables appeared to be more frequently contaminated in the summer. This trend extended to both imported and domestic leafy vegetables, and was particularly strong in organic produce. Several studies on this subject [15-17] found that organic produce was more susceptible to bacterial contamination. Our findings support this observation and indicate that summertime is the prime period to observe this difference in hygienic quality in organic leafy vegetables.

Results of this study suggest that fresh vegetables commonly purchased from grocery stores in Ukraine are a source for bacterial species and a public health concern. All eight bacteria studied belong to the group of pathogens that cause the majority of nosocomial infections. The predominant contamination of antibiotic-resistant bacteria were: E. coli, Enterobacter spp. and E. faecalis, followed by K. pneumoniae, P. aeruginosa, S. aureus and Acinetobacter spp. S.aureus were cultured most often from tomatoes (14.2\%) and cucumbers (10.3\%), E. faecalis from cucumbers (26.7\%) and tomatoes (23.9\%), E.faecium from berries $(8.3 \%)$, green onions $(6.7 \%)$ and leafy vegetables (6.7\%), E.coli from leafy herbs (42.6\%), leafy vegetables $(40.2 \%)$ and berries (34.1\%), Enterobacter spp. from leafy herbs (25.1\%) and green onions (20.4\%), K. pneumoniae from cucumbers (13.5\%), green onions (13.3\%), berries $(13.2 \%)$ and tomatoes (13\%), P. aeruginosa from green onions (11.7\%), berries (7.5\%) and leafy vegetables $(6.5 \%)$, Acinetibacter spp. from tomatoes (3.4\%), cucumbers (3.4\%) and green onions $(3.2 \%)$.

According to the literature, vegetables produced in or close to soil - such as leaf vegetables are at special risk for contamination with soil-borne bacteria, either belonging to natural soil microbiota or introduced into soil by manure fertilization [18]. In 2007, the FAO and WHO convened an expert committee to establish priority commodities of concern in terms of microbiological hazards associated with fresh produce and leafy vegetables and leafy herbs were given the highest level of priority, followed by berries, green onions, melons, sprouted seeds and tomatoes [4].

In our study the overall proportion of extended spectrum beta-lactamase (ESBL) production among Enterobacteriaceae was $36.8 \%$ and of methicillin-resistance in S. aureus (MRSA) 10.7\%. The prevalence of ESBL production among E. coli isolates was significantly higher than in K.pneumoniae. Vancomycin resistance was observed in $3.1 \%$ of isolated enterococci (VRE). Carbapenem resistance was identified in $35.3 \%$ of P.aeruginosa isolates and $66.8 \%$ of Acinetibacter spp. isolates. Resistance to third-generation cephalosporins was observed in 9.7\% K.pneumoniae and E.coli in $14.2 \%$ isolates.

The potential for transfer of antimicrobial-resistant bacteria from fresh vegetables into the human population is cause for concern. However, to date, few studies have focused on the occurrence of antimicrobial-resistant commensally bacteria in fresh vegetables sold at retail. Several studies are accessible regarding major anti- microbial-resistant bacteria (e.g., Enterobacteriaceae, Pseudomonas spp., Gram-positive cocci). These studies revealed vegetables to be a potential-although rare-vector for extended-spectrum beta-lactamase-producing Enterobacteriaceae, colistin- and carbapenem-resistant Pseudomonas aeruginosa, linezolid-resistant enterococci and staphylococci, and vancomycin-resistant enterococci [18]. Resistance data for isolates differed significantly between studies; this might be related to the very different geographical locations, the different nature of fresh vegetable samples, and the different choice of antibiotics and breakpoints. Korean leafy vegetables were contaminated with MRSA strains [19]. Vancomycin-teicoplanin-resistant enterococci were isolated from fresh produce in Korea [20]. Linezolid-resistant strains of E. faecalis and E. faecium were isolated from German vegetables [21]. Resistance in E. faecalis isolates from Portuguese ready-to-eat salad was restrained to tetracyclines and erythromycin [22]. One linezolid-resistant E. faecium was detected in Canadian vegetables as well [23]. From Tunisia [24] reported resistance Enterococcus species to high level concentrations of aminoglycosides and chloramphenicol. Gómez-Aldapa et al. [25] reported $100 \%$ resistance to amikacin and colistin in E. coli pathotypes from Mexican cactus salads. Resistance in $E$. coli isolates from raw vegetables at a retail market in the Czech Republic was restrained to tetracyclines [26]. One study identified significantly higher resistance rates to aminoglycosides in Pseudomonas isolates from fruit vegetables compared with root vegetables or salads [21].

The results this study adds to the global knowledge base regarding the prevalence and characteristics of antibiotic-resistant bacteria in fresh vegetables required for future risk analysis. Prevalence of antimicrobial resistance among gram-positive and gram-negative organisms, the ability of antibiotic-resistant bacteria to persist in hospitals and the environment, and possible transfer of resistance genes from this pathogens to other endogenous human flora or pathogens is reason for concern in the health care setting. Therefore, the impact of contamination of fresh vegetables with antibiotic-resistant pathogens and prophylactics and their possible cross-resistance with antimicrobials used to treat human infections should be investigated further with the goal of reducing the number of infections and fatalities associated with bacterial infections.

\section{CONCLUSIONS}

The results of this study indicate that the contamination of fresh vegetables with antibiotic-resistant bacteria at levels representing a risk to public health was found to be frequent and widespread occurrence in the Ukrainian marketplace. This trend extended to both imported and domestic fresh vegetables, and was particularly strong in domestic organic produce. This finding suggests that food safety practices carried out by the different players along the food supply chain, from agricultural practices by the farmers to handling practices by the food distributors 
and vendors are generally not sufficient. Food producers, distributors and vendors should minimize the risk of contamination of fresh vegetables with antibiotic-resistant bacteria, and ensure in the production, transportation, storage and sale of fresh vegetables of acceptable quality and safety. It is necessary to ensure provide food safety oversight of the regulated parties and to promote safe production and handling of foods throughout the entire food production chain.

\section{REFERENCES}

1. Denis N., Zhang H., Leroux A., et al. Prevalence and trends of bacterial contamination in fresh fruits and vegetables sold at retail in Canada. Food Control. 2016; 67:225-234. doi:10.1016/j.foodcont.2016.02.047

2. Berger C.N., Sodha S.V., Shaw R.K., et al. Fresh fruit and vegetables as vehicles for the transmission of human pathogens. Environ Microbiol. 2010;12(9):2385-97. doi: 10.1111/j.1462-2920.2010.02297.x.

3. Lynch M.F., Tauxe R.V., Hedberg C.W. The growing burden of foodborne outbreaks due to contaminated fresh produce: risks and opportunities. Epidemiol Infect. 2009;137(3):307-15. doi: 10.1017/ S0950268808001969.

4. FAO/WHO. Microbiological hazards in fresh fruits and vegetables. [Online] Available from: http://www.fao.org/fileadmin/templates/ agns/pdf/jemra/FFV_2007_Final.pdf [Accessed 20th June 2008].

5. FAO/WHO. Microbiological risk assessment series 14: Microbiological hazards in fresh leafy vegetables and herbs. [0nline] Available from: ftp://ftp.fao.org/docrep/fao/011/i0452e/i0452e00.pdf [Accessed 20th June 2008].

6. PHAC Public Health Agency of Canada. Outbreak of E. coli 0157:H7 associated with lettuce served at fast food chains in the Maritimes and Ontario, Canada, Dec 2012 (2014). Canada Communicable Disease Report CCDR, 40 S-1 [Online] Available from: http://phac-aspc.gc.ca/ publicat/ccdr-rmtc/14vol40/dr-rm40s-1/dr-rm40s-1-ecoli-eng.php [Accessed 27th June 2015].

7. Grant J., Wendelboe A.M., Wendel A., et al. Spinach-associated Escherichia coli 0157:H7 outbreak, Utah and New Mexico, 2006. Emerg Infect Dis. 2008;14(10):1633-1636. doi:10.3201/eid1410.071341

8. Wendel A.M., Johnson D.H., Sharapov U., et al. Multistate outbreak of Escherichia coli 0157:H7 infection associated with consumption of packaged spinach, August-September 2006: The Wisconsin investigation. Clin Infect Dis. 2009;48(8):1079-1086. doi: 10.1086/597399

9. Elviss N.C., Little C.L., Hucklesby L., et al. Microbiological study of fresh herbs from retail premises uncovers an international outbreak of salmonellosis. Int J Food Microbiol. 2009;134(1-2):83-8. doi: 10.1016/j. ijfoodmicro.2009.01.015.

10. Pezzoli L., Elson R., Little C.L., et al. Packed with Salmonella-investigation of an international outbreak of Salmonella Senftenberg infection linked to contamination of prepacked basil in 2007. Foodborne Pathog Dis. 2008:5(5):661-8. doi: 10.1089/fpd.2008.0103.

11. Hanning I.B., Nutt J.D., Ricke S.C. Salmonellosis outbreaks in the United States due to fresh produce: sources and potential intervention measures. Foodborne Pathog Dis. 2009;6(6):635-48. doi: 10.1089/ fpd.2008.0232.

12. Byrne L., Fisher I., Peters T., et al. A multi-country outbreak of Salmonella Newport gastroenteritis in Europe associated with watermelon from Brazil, confirmed by whole genome sequencing: October 2011 to January 2012. Euro Surveill. 2014;19(31):6-13. doi: 10.2807/1560-7917. es2014.19.31.20866.
13. Salmanov A.G., Vdovychenko S.Y., Litus 0.I., et al. Prevalence of health care-associated infections and antimicrobial resistance of the responsible pathogens in Ukraine: Results of a multicenter study (2014-2016). Am J Infect Control. 2019;47(6):e15-e20. doi: 10.1016/j. ajic.2019.03.007.

14. Salmanov A., VozianovS., Kryzhevsky V., et al. Prevalence of healthcareassociated infections and antimicrobial resistance in acute care hospitals in Kyiv, Ukraine. J Hosp Infect. 2019;102(4):431-437. doi: 10.1016/j. jhin.2019.03.008.

15. Mukherjee A., Speh D., Dyck E., et al. Preharvest evaluation of coliforms, Escherichia coli, Salmonella, and Escherichia coli 0157:H7 in organic and conventional produce grown by Minnesota farmers. J Food Prot. 2004;67(5):894-900. doi: 10.4315/0362028x-67.5.894.

16. Oliveira M., Usall J., Viñas I., et al. Microbiological quality of fresh lettuce from organic and conventional production. Food Microbiol. 2010;27(5):679-84. doi: 10.1016/j.fm.2010.03.008.

17. Tango C.N., Choi N.J., Chung M.S., et al. Bacteriological quality of vegetables from organic and conventional production in different areas of Korea. J Food Prot. 2014;77(8):1411-7. doi: 10.4315/0362-028X. JFP-13-514.

18. Hölzel C.S., Tetens J.L., Schwaiger K. Unraveling the Role of Vegetables in Spreading Antimicrobial-Resistant Bacteria: A Need for Quantitative Risk Assessment. Foodborne Pathog Dis. 2018;15(11):671-688. doi: 10.1089/fpd.2018.2501.

19. Hong J., Kim Y., Kim J., et al. Genetic Diversity and Antibiotic Resistance Patterns of Staphylococcus Aureus Isolated from Leaf Vegetables in Korea. J Food Sci. 2015;80(7):M1526-31. doi: 10.1111/17503841.12909.

20. Kim M.-C., Cha M.-H., Ryu J.-G., et al. Characterization of vancomycinresistant Enterococcus faecalis and Enterococcus faecium isolated from fresh produces and human fecal samples. Foodborne Pathog Dis. 2017;14 (4):195-201. doi: 10.1089/fpd.2016.2188

21. Schwaiger K., Helmke K., Hölzel C.S., et al. Antibiotic resistance in bacteria isolated from vegetables with regards to the marketing stage (farm vs. supermarket). Int J Food Microbiol. 2011;148(3):191-6. doi: 10.1016/j.jiffoodmicro.2011.06.001.

22. Campos J., Mourão J., Pestana N., et al. Microbiological quality of ready-to-eat salads: an underestimated vehicle of bacteria and clinically relevant antibiotic resistance genes. Int J Food Microbiol. 2013;166(3):464-70. doi: 10.1016/j.ijfoodmicro.2013.08.005.

23. Allen K.J., Kovacevic J., Cancarevic A., et al. Microbiological survey of imported produce available at retail across Canada. Int J Food Microbiol. 2013;162(2):135-42. doi: 10.1016/j.ijfoodmicro.2013.01.010.

24. Ben Said L., Klibi N., Dziri R., et al. Prevalence, antimicrobial resistance and genetic lineages of Enterococcus spp. from vegetable food, soil and irrigation water in farm environments in Tunisia. J Sci Food Agric. 2016;96(5):1627-33. doi: 10.1002/jsfa.7264.

25. Gómez-Aldapa C.A., Cerna-Cortes J.F., Rangel-Vargas E., et al. Presence of Multidrug-Resistant Shiga Toxin-Producing Escherichia coli, Enteropathogenic E. coli and Enterotoxigenic E. coli, on Raw Nopalitos (Opuntia ficus-indica L.) and in Nopalitos Salads from Local Retail Markets in Mexico. Foodborne Pathog Dis. 2016;13(5):269-74. doi: 10.1089/fpd.2015.2065.

26. Skočková A., Karpišková R., Koláčková I., et al. Characteristics of Escherichia coli from raw vegetables at a retail market in the Czech Republic. Int J Food Microbiol. 2013;167(2):196-201. doi: 10.1016/j. ijfoodmicro.2013.09.011. 


\section{Funding:}

This work is a fragment of a research study of the Scientific Research Laboratory of Shupyk National Medical Academy of Postgraduate Education (Kyiv, Ukraine). Title: The scientific justification for measures to combat the resistance of microorganisms to antimicrobial drugs in Ukraine on the \&quot;One Health\&quot; approaches. State Registration Number: 0120U101440. Study period:2020-2022. This work was funded by the Ministry of Health of Ukraine according to the plan of that research study. The authors did not receive any financial support from the manufacturers of medical instruments and drugs.

\section{Acknowledgements}

We would like to thank the Ministry of Health of Ukraine for support this work.

\section{ORCID and contributorship:}

Aidyn G. Salmanov: 0000-0002-4673-1154 A,C,D,E,F

Valerii O. Ushkalov: 0000-0001-5694-632X ${ }^{B, C, D, F}$

Yelizaveta Ye. Shunko: 0000-0002-4883-2549 ${ }^{B, C, D, F}$

Natalie Piven: 0000-0002-1533-4981 B,C,D,F

Liliia M. Vygovska: 0000-0002-5631-9139 B,C,F

Olha M. Verner: 0000-0002-7588-5742 B,C,F

Stella Kushnirenko: 0000-0001-5518-7210 B,C,F

\section{Conflict of interest:}

The Authors declare no conflict of interest

\section{CORRESPONDING AUTHOR}

Aidyn G. Salmanov

Shupyk National Medical Academy of Postgraduate Education, St. Dorohozhytska 9, 04112, Kyiv, Ukraine

tel: +380667997631

e-mail:mozsago@gmail.com

Received: 13.08 .2020

Accepted: 07.12 .2020

A - Work concept and design, B - Data collection and analysis, C - Responsibility for statistical analysis,

D-Writing the article, $\mathbf{E}$-Critical review, $\mathbf{F}$ - Final approval of the article 